\title{
Vascular plant and bryophyte species richness in response to water quality in lowland spring niches with different anthropogenic impacts
}

\author{
Katarzyna Puczko (iD • Piotr Zieliński • Szymon Jusik • \\ Anita Kołakowska • Elżbieta Jekatierynczuk-Rudczyk
}

Received: 27 December 2017 / Accepted: 24 April 2018 / Published online: 10 May 2018

(C) The Author(s) 2018

\begin{abstract}
Many freshwater ecosystems face severe threats from anthropogenic disturbances. In the field, we investigated the morphology of spring niches and the species richness of vascular plants and bryophytes in 16 springs, draining the quaternary aquifers, located in two different environments - an urban area (city of Białystok) and a protected area (Knyszyn Forest Landscape Park, NE Poland). In total, 47 vascular plant and 45 bryophyte species were recorded, representing mostly crenophytes including protected species. The most important water quality parameters that can be used to evaluate variations of the spring water chemistry in NE
\end{abstract}

\author{
E. Jekatierynczuk-Rudczyk \\ Poland \\ e-mail: k.puczko@uwb.edu.pl \\ P. Zieliński \\ e-mail: p.zielinski@uwb.edu.pl \\ A. Kołakowska \\ e-mail: anitakolakowska@wp.pl \\ E. Jekatierynczuk-Rudczyk \\ e-mail: rudczyk@uwb.edu.pl
}

K. Puczko $(\bowtie) \cdot$ P. Zieliński · A. Kołakowska •

Department of Environmental Protection, Institute of Biology, University of Bialystok, Ciołkowskiego 1J, 15-245 Białystok,

S. Jusik

Department of Ecology and Environmental Protection, Poznan University of Life Sciences, Wojska Polskiego 28, 60-637 Poznań, Poland

e-mail: jusz@up.poznan.pl
Poland are the mineral-related parameters (electrolytic conductivity, $\mathrm{Ca}^{2+}, \mathrm{SO}_{4}{ }^{2-}$, and $\mathrm{Cl}^{-}$). The organic-related parameters (DOC) and nutrients $\left(\mathrm{TP}, \mathrm{NO}_{3}{ }^{-}-\mathrm{N}\right)$ were negatively involved in water quality variations. Our results show that anthropogenic activity significantly affects the biodiversity of plant communities in lowland springs. The presence or absence of crenophytes and bryophytes is indicative of the ecological status of the groundwater outflow complexes.

Keywords Springs · Plants · Plant biodiversity · Crenophytes $\cdot$ Water chemistry

\section{Introduction}

Natural outflows of groundwater are complex ecosystems in both hydrological and biotic terms. They are characterized, in most cases, by a high biodiversity of flora and fauna (Springer and Stevens 2009; Warncke 1980). Springs occur more frequently in mountains and upland areas, and there are fewer reports on the biology and ecology of typical springs in lowlands of Central Europe (Chełmicki et al. 2011; Osadowski and Strzelczak 2010). Further, their presence in urban areas is very rare (Jekatierynczuk-Rudczyk 2008).

Erosion activity by spring waters causes a spring niche to develop. Springs have been considered to be stabile habitats that harbor stable communities (Juutinen 2011). Spring niches such as algae habitats indicate the species richness of diatoms (Żelazna-Wieczorek and Maninska 2006; Wojtal 2013). Springs are inhabited 
by highly specialized plants that are highly tolerant of low water temperature, so-called crenophytes. Natural outflows of groundwater are an important element of a hydrographic network shaping water relations in a particular area and directly affecting the water balance of a catchment. Within the spring niche, the energy exchange processes at the soil-water-air interface mean that in temperate climates, the outflows never freeze (Czarnecka and Janiec 2007).

Plant communities of springs differ from other plant communities by their dependence on permanent, relatively cold water abundant in oxygen. In the spring niches where plant cover is developed, water cannot easily flow away, and the soil water reserve can thus be enriched (Hadač 1983). Differentiation of environmental factors affects the abundance and distribution of plants associated with outflows of groundwater. The decisive factors are those directly related to the outflow, such as geological structure, types of sediments, topography, climate, and hydrology, which affect the water quality (Lacoul and Freedman 2006; Michalik 2008). Habitat conditions (primarily in terms of the substrate) within the niche are largely mosaic, and this is reflected in their floristic diversity. Mid-forest springs are characterized by particular floristic abundance, containing abundant bryophytes and vascular plants from different habitats: aquatic, peat, reed, and forest species (Kucharski 2007).

Urban flora and vegetation have specific features and differ significantly from those of surrounding nonurbanized areas (McKinney 2008). Urban infrastructure replaces open land and vegetation, and surfaces that were permeable and moist generally become impermeable and dry (Rysiak and Czarnecka 2015). The most consistent and pervasive effect of urbanization is an increase in an impervious surface cover within urban catchments, altering the hydrology and geomorphology of streams and springs.

The relationship between spring location and environmental characteristics in lowlands has not been studied extensively. The aim of this paper is to compare the vegetation of lowland spring niches in areas with varying degrees of anthropogenic transformation, as well as to study the impact of water quality on the phytocoenosis of springs. We seek to determine what would form the main habitat gradient that could affect community composition for both angiosperms and mosses. We hypothesized that spring hydrochemistry affects bryophytes more strongly than vascular plants.

\section{Materials and methods}

Study area

The study was conducted in northeastern Poland, in the area of Knyszyn Forest Landscape Park (KFLP) and in the city of Białystok (Fig. 1). This area is distinguished by a complex hydrographic network that owes its shape to varied terrain formed during the Weichselian glaciation. The area is characterized by the presence of moraine plateaus, the slopes of which are cut by numerous valleys. The outflows of groundwater in the study area are usually located on the slopes of valleys and occasionally in the valley bottoms and riverbeds (JekatierynczukRudczyk et al. 2017; Jonczak 2013).

KFLP is one of the best preserved forest complexes in Poland that contains varied postglacial sculpture, typical forest streams, and springs. The surface waters in KFLP are almost entirely located in the catchment of Supraśl river (Fig. 1). In KFLP, most of the natural outflows of groundwater are the valley type. The yield of the forest springs varies from 0.02 to $27 \mathrm{dm}^{3} \mathrm{~s}^{-1}$. However, the most common yield for the forest springs is 0.1 to $0.5 \mathrm{dm}^{3} \mathrm{~s}^{-1}$ (Jekatierynczuk-Rudczyk 2010).

Białystok, a city with a population of over 280,000 residents, lies in the immediate vicinity of the forest (Fig. 1). The area of the city is mostly deforested, and hydrological conditions are significantly changed. The geological and geomorphological structures are the same types as in the area of KFLP. The area is built from postglacial formations developed during the areal deglaciation of the Weichselian ice sheet. Despite the ongoing horizontal and vertical transformations of surface and groundwaters, the Białystok region still has a well-preserved natural environment, which is confirmed by the presence of spring niches (Jekatierynczuk-Rudczyk 2008). The springs are located in partly forested areas, with the exception of one limnocrene located in a housing estate. The average yields of the investigated urban outflows range from 0.1 to $5.0 \mathrm{dm}^{3} \mathrm{~s}^{-1}$. Bialystok springs are more exposed to anthropogenic contaminations than are KFLP springs due to leaks in the sewerage network and to surface contamination in infiltration zones and from local landfills. The water quality in urban springs is also endangered by the dense transportation network and the progressive development of the city. 


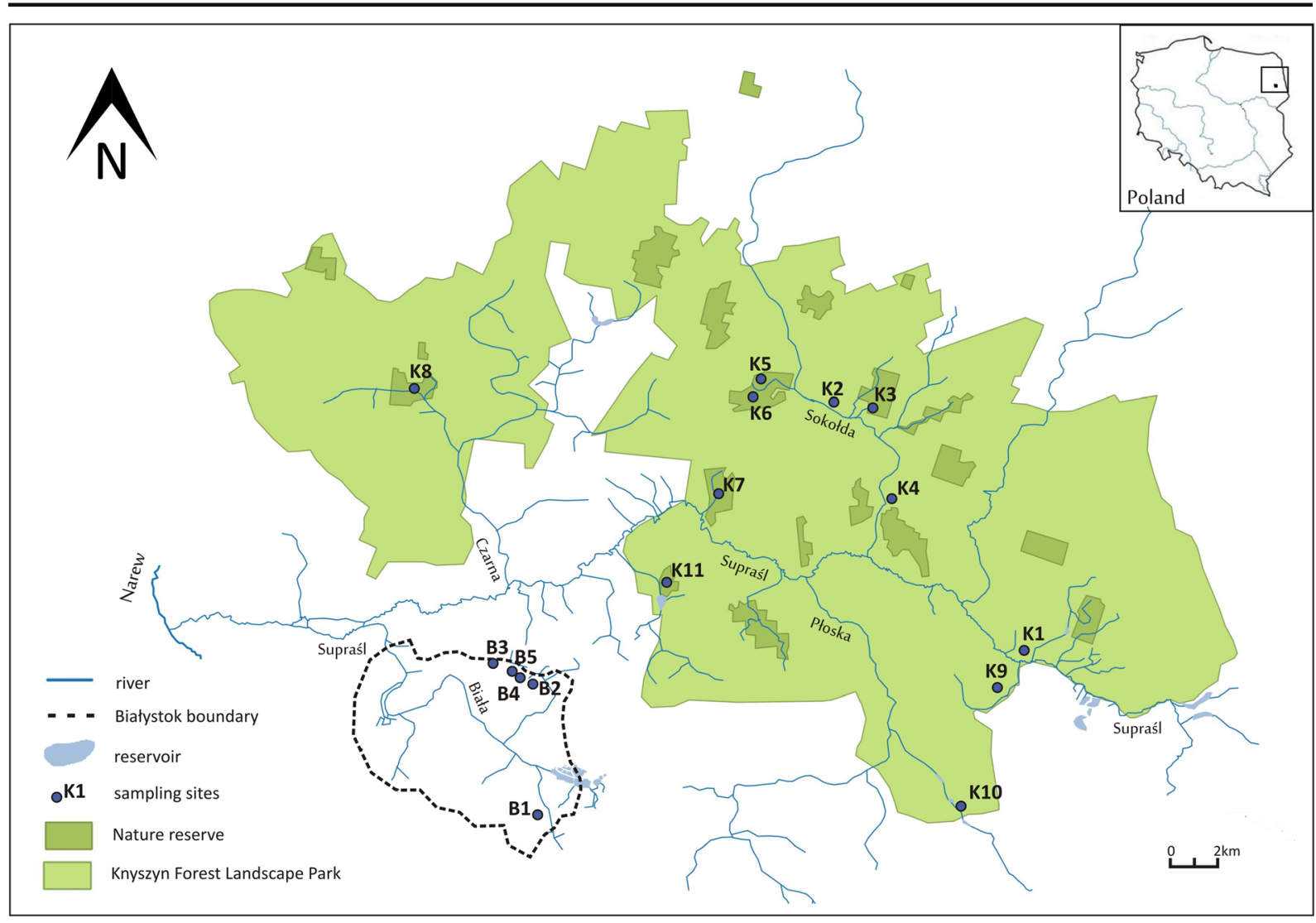

Fig. 1 The distribution of study sites in northeastern Poland. Springs in Białystok city are indicated with B1-B5, springs in KFLP are indicated with K1-K11. Coordinates presented along the edges are in ETRS89/Poland CS92

Methods

The study included 11 forested spring niches located in the area of KFLP and 5 urban spring niches in the city of Białystok (Fig. 1, Table 1). The surface area and saturation zone structure of the spring niches were specified directly in the field. In each of the studied niches, the following three zones can be distinguished: exfiltration of groundwater in the footslope zones, the hyporheic zone covering niche bottoms, and the stream flowing out of the channel head. The detailed study included the flora occupying the hyporheic zone/watered part of the spring niche. The outer boundaries of each spring were delineated to the edge of the niche slope. Studies have not been conducted in the outflow zone, where habitat conditions were considerably altered due to increased flow rate. A land use indicator was developed based on the CORINE land cover data set.

The study of vascular plants and bryophytes was carried out in August 2015, in the middle of the growing season. All plants were determined to the species level, and the quantity and sociability of individual plant species were determined using the Braun-Blanquet scale (Braun-Blanquet 1932). Taxonomic nomenclature of vascular plants was adopted based on Mirek et al. (2002), mosses according to Ochyra et al. (2003), and liverworts after Szweykowski (2006). Plant name abbreviations have been created from six-letter codes, for example Lemna minor-Lemmin.

Hydrochemical studies were conducted at the same time as the identification of plant species. Water temperature, $\mathrm{pH}$, electrolytic conductivity (EC), oxygen concentration, and water saturation with oxygen were determined with a HachLange multiparameter probe (HQ40). Chemical water analyses were carried out in accordance with ISO standards, by means of methods described previously (APHA 1992). The following analyses were performed: calcium $\left(\mathrm{Ca}^{2+}\right)$ by means of titration with disodium EDTA against calcite, sulfate $\left(\mathrm{SO}_{4}{ }^{2-}\right)$ by the nephelometric method with barium chloride, chloride $\left(\mathrm{Cl}^{-}\right)$by a method with mercury thiocyanate, ammonium nitrogen $\left(\mathrm{NH}_{4}{ }^{+}-\mathrm{N}\right)$ by the indophenol 


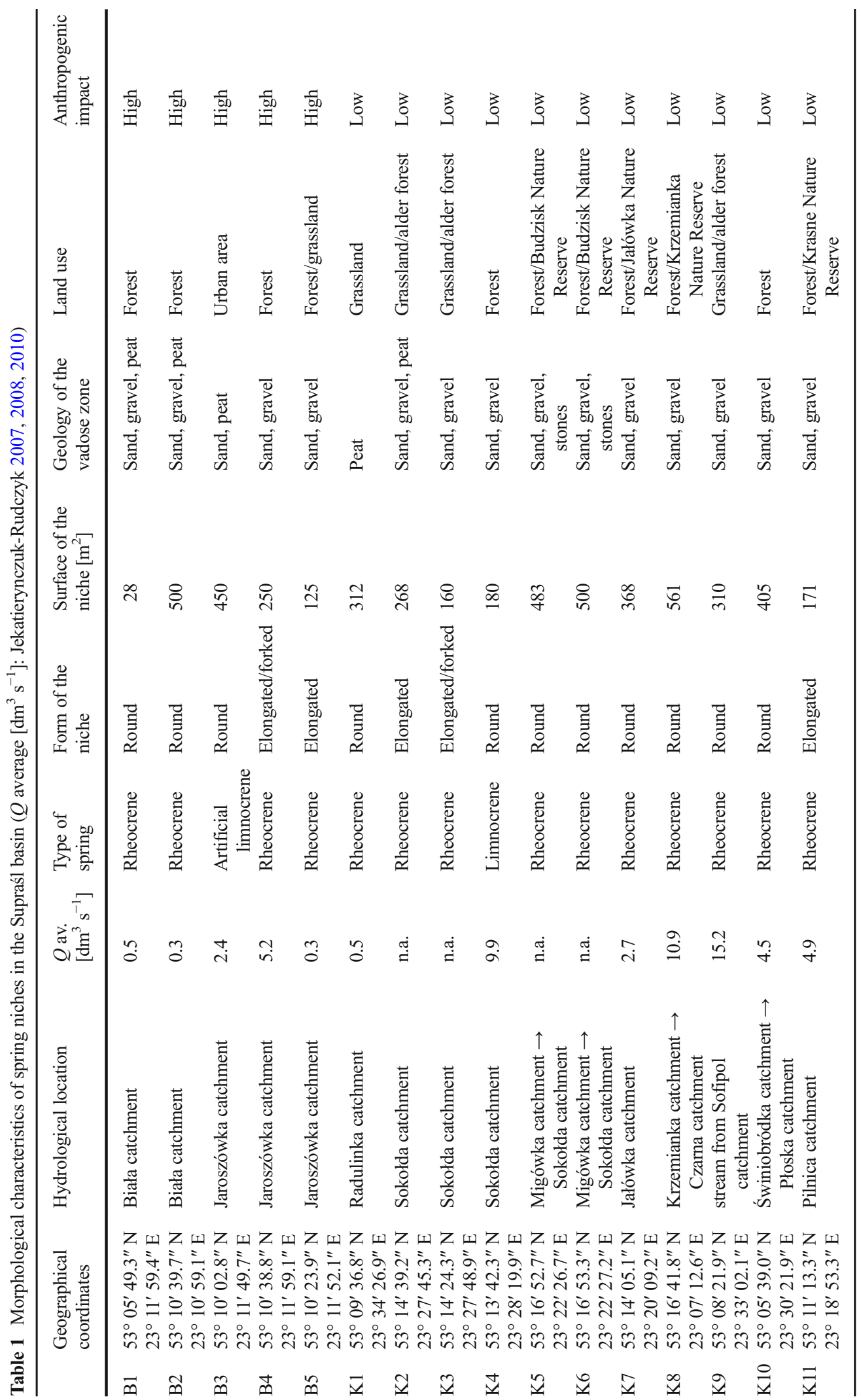


method, and nitrate nitrogen $\left(\mathrm{NO}_{3}{ }^{-} \mathrm{N}\right)$ by the reduction method with $N$-(1-naphthyl) ethylenediamine. The remaining water chemical parameters were determined by the spectrophotometric method with SpectraMax M2 with the application of procedures and reagents by Riedel-de Haen. Soluble reactive phosphorus (SRP) was determined by the molybdenum method after filtering through a "GF/C" filter, total phosphorus (TP) by the molybdenum method after prior acidification, and mineralization with UV light. The concentration of dissolved organic carbon (DOC) was determined with a Shimadzu TOC-L analyzer according to the method described by Zieliński and Górniak (1999).

Data analysis

Species richness parameters were determined for each community type, separately for bryophytes and vascular plants. We measured species diversity as calculated according to Shannon's formula (Shannon and Weaver 1963):

$H^{\prime}=-\sum_{i=1}^{R} p_{i} \ln p_{i}$

$p_{i} \quad$ proportion of total cover in the stream represented by the species

The index of floral originality (IFO) was determined by using the number of rare species and/or elusive species (Ejsmont-Karabin 1995):

$\mathrm{IFO}=\frac{\sum_{i=1}^{k} \frac{1}{m_{i}}}{s} \times 100 \%$

IFO index of floral originality

$m$ the number of trials (number of spring niches) in which the species occurs

$s \quad$ the number of species per sample (spring niche)

The statistical analyses were conducted with the application of XLSTAT 2016.1. and PS IMAGO 4.0. Spearman correlation was used to find relationships between bryophyte and vascular plant species richness within each spring niche. Principal component analysis (PCA) (Ouyang 2005) and principal factor analysis (PFA) were used to determine the number of principal components or factors to be retained for further study. A commonly used criterion for the number of factors to rotate is the eigenvalues-greater-than-one rule proposed by Kaiser (1960). An eigenvalue less than one implies that the scores on the component would have negative reliability, and there are as many reliable factors as there are eigenvalues greater than one (Cliff 1988).

Canonical correspondence analysis (CCA) was used for relating the composition of macrophytes to environmental variables. CCAs are not always appropriate for composition data, but community ecologists have repeatedly argued that the Euclidean distance is inappropriate for raw species abundance data involving null abundances (Legendre and Legendre 1998). Moreover, CCA can be used in short and long gradients of species data (Legendre and Gallagher 2001). Two-way MANOVA was used for testing differences among springs, with spring area as a covariate. The significance of differences of mean values of biodiversity indicators between springs located in Białystok city and in KFLP was assessed using Statistica 12.5 software, separately for vascular plants and bryophytes. Prior to the analysis, two assumptions were verified: the normality of data distribution and variance homogeneity. To assess the normality of distribution of variables in groups, the Shapiro-Wilk test and analysis of categorized normality charts were used. Based on the test probabilities $p \leq$ 0.05 , no grounds were found to reject the assumptions on normality of distributions of all analyzed parameters. The assumption of variance homogeneity was verified applying Levene's test and the Brown-Forsythe test. Results obtained from Levene's test indicate failure to meet the variance homogeneity assumption $(p<0.05)$ for all biodiversity indicators (except from IFO) calculated for vascular plants. Because the assumption of normal data distribution was met and the assumption of homogeneity of variance was not, Welch's $t$ test for independent samples was applied.

\section{Results}

Morphology of spring niches

The average area of spring niche in the KFLP was $338 \mathrm{~m}^{2}\left(\max =561 \mathrm{~m}^{2}, \min =160 \mathrm{~m}^{2}\right)$, whereas in the urban area, it was $25 \%$ lower $\left(\max =500 \mathrm{~m}^{2}\right.$, $\min =$ $28 \mathrm{~m}^{2}$ ). Over $75 \%$ of studied spring niches were characterized by sandy-gravel bottom (Table 1). The bottoms of other niches were filled with sandy formations and, rarely, gravel with a thick detritus layer. In terms of 
hydrobiology, the majority of outflows were characterized as rheocrene springs, descensive outflows in which groundwater leaks and is filtered from the bottom and niche edges and then flows as a concentrated stream in accordance with the natural land decline. Spring no. B5, located in the Jaroszówka stream valley, was defined as an ascensive outflow, displaying the pulsation of water under low hydrostatic pressure with a direction opposite from gravity. Ascensive outflows are very rare in lowland areas. The study involved two limnocrenes: one from the forested area in KFLP and one artificial limnocrene from the urban environment in Białystok. Due to their location and relationship to the area morphology, most springs were classified as valley-edge, and only a few occurred in the river valleys (Table 1). The anthropogenic impact on spring niches was determined by the distance from built-up areas and communication routes.

\section{Chemical characteristic of spring water}

Tested water from springs was characterized by slight alkalinity $(\mathrm{pH}=7.8-8.2)$. Statistically significant differences between water chemistry of urban and natural spring niche location were identified for $\mathrm{pH}, \mathrm{EC}$, the concentrations of calcium, total iron, ammonium, and nitrate ions; and the concentration of DOC (Table 2). A correlation matrix of chemical variables is presented in Table 3 .

PFA results show that the first five principal factors have eigenvalues greater than unity and explain, respectively, $43.6,17.5,13.0,10.0$, and $5.8 \%$ of the total variances in the original data set. Therefore, the first five factors were used for further analysis. Table 4 shows squared cosines of the variables for the first five factors. The most important water quality parameters that can be used to evaluate variations of the spring water chemistry in NE Poland are the mineral-related parameters (electrolytic conductivity, $\mathrm{Ca}^{2+}, \mathrm{SO}_{4}{ }^{2-}$, and $\mathrm{Cl}^{-}$). They may be interpreted as representing influences from both natural and anthropogenic inputs. The organic-related parameters (DOC) and nutrients $\left(\mathrm{TP}, \mathrm{NO}_{3}{ }^{-} \mathrm{N}\right)$ were negatively involved in water quality variations. They may be interpreted as representing influences from natural inputs. Graphical presentation of the relationships based on spring water variables showed ordering of the niches along the water gradients (Fig. 2). Spring niches no. B1, B2, B3, and B5 located in the urban area were characterized by high concentrations of mineral ions, in contrast to spring niches no. K1-K10, based on the concentrations of nutrients and DOC.

The ordination of samples and variables on the PCA biplot is depicted in Fig. 2; the variability explained by the first axis is $43.59 \%$, while that explained by the second is $17.49 \%$. Samples from the KFLP are shown within the left side of the biplot, while the right side is occupied by samples from the Białystok spring niches. The two axes in the biplots, as well as the positions of the sites, are distorted (Fig. 2). Total phosphorus, calcium ions, and sulfates are positively associated with the distribution of the spring niche samples in Białystok along the horizontal axis. The position of each variable on the biplot is not necessarily identified with the

Table 2 Summary statistics for spring water chemistry (significant differences calculated with the Mann-Whitney $U$ test, $p<0.05$ )

\begin{tabular}{|c|c|c|c|c|c|c|c|c|c|c|}
\hline \multicolumn{2}{|l|}{ Stands } & \multicolumn{4}{|c|}{ Springs B1-B5 } & \multicolumn{4}{|c|}{ Springs K1-K11 } & \multirow{2}{*}{$\begin{array}{l}\text { Statistical difference } \\
\text { ( } p \text { value) }\end{array}$} \\
\hline Parameters & Unit & Average & Median & Min & $\operatorname{Max}$ & Average & Median & Min & Max & \\
\hline $\mathrm{pH}$ & & 8.2 & 7.9 & 7.6 & 9.0 & 7.8 & 7.8 & 7.2 & 8.6 & 0.002 \\
\hline $\mathrm{EC}$ & $\mu \mathrm{S} \mathrm{cm}{ }^{-1}$ & 589 & 580 & 364 & 897 & 394 & 395 & 149 & 588 & 0.036 \\
\hline $\mathrm{Ca}^{2+}$ & $\mathrm{mg} \mathrm{dm}{ }^{-3}$ & 101.3 & 103.2 & 73.3 & 139.4 & 73.6 & 72.9 & 25.5 & 98.8 & 0.047 \\
\hline $\mathrm{Cl}^{-}$ & $\mathrm{mg} \mathrm{dm}^{-3}$ & 18.3 & 20.1 & 7.7 & 29.9 & 10.1 & 9.1 & 3.6 & 41.5 & 0.396 \\
\hline $\mathrm{SO}_{4}{ }^{2-}$ & $\mathrm{mg} \mathrm{dm}{ }^{-3}$ & 85.0 & 88.6 & 39.3 & 117.9 & 53.0 & 49.2 & 14.1 & 87.0 & 0.062 \\
\hline Total Fe & $\mathrm{mg} \mathrm{dm}{ }^{-3}$ & 1.54 & 1.25 & 0.57 & 3.55 & 0.84 & 0.60 & 0.13 & 4.00 & 0.002 \\
\hline DOC & $\mathrm{mg} \mathrm{dm}{ }^{-3}$ & 4.5 & 3.5 & 2.6 & 9.5 & 5.6 & 3.8 & 1.0 & 22.1 & 0.036 \\
\hline $\mathrm{NO}_{3}{ }^{-}-\mathrm{N}$ & $\mu \mathrm{g} \mathrm{dm}{ }^{-3}$ & 310 & 120 & 25 & 1334 & 617 & 203 & 66 & 4576 & 0.002 \\
\hline $\mathrm{NH}_{4}{ }^{+}-\mathrm{N}$ & $\mu \mathrm{g} \mathrm{dm}{ }^{-3}$ & 129 & 129 & 63 & 233 & 167 & 174 & 32 & 345 & 0.002 \\
\hline Total P & $\mu \mathrm{g} \mathrm{dm}^{-3}$ & 73 & 60 & 37 & 164 & 83 & 68 & 28 & 167 & 0.234 \\
\hline
\end{tabular}

Values in italic are significant at 0.05 level 
Table 3 Correlation matrix (Pearson $(n)$ ) of the chemical parameters of spring water

\begin{tabular}{lcccccccrrr}
\hline Variables & $\mathrm{pH}$ & $\mathrm{EC}$ & $\mathrm{Ca}^{2+}$ & $\mathrm{Cl}^{-}$ & $\mathrm{SO}_{4}{ }^{2-}$ & $\mathrm{Total} \mathrm{Fe}$ & $\mathrm{DOC}$ & $\mathrm{NO}_{3}{ }^{-}-\mathrm{N}^{2}$ & $\mathrm{NH}_{4}{ }^{+}-\mathrm{N}$ & $\mathrm{Total} \mathrm{P}^{-}$ \\
\hline $\mathrm{pH}$ & 1 & 0.457 & -0.441 & 0.853 & 0.827 & 0.809 & -0.029 & -0.485 & -0.369 & 0.061 \\
$\mathrm{EC}$ & 0.457 & 1 & -0.249 & 0.428 & 0.568 & 0.418 & 0.010 & -0.495 & -0.043 & -0.344 \\
$\mathrm{Ca}^{2+}$ & -0.441 & -0.249 & 1 & -0.345 & -0.167 & -0.318 & 0.242 & 0.000 & -0.181 & -0.041 \\
$\mathrm{Cl}^{-}$ & 0.853 & 0.428 & -0.345 & 1 & 0.750 & 0.773 & 0.309 & -0.480 & -0.532 & 0.096 \\
$\mathrm{SO}_{4}{ }^{2-}$ & 0.827 & 0.568 & -0.167 & 0.750 & 1 & 0.615 & 0.118 & -0.603 & -0.503 & -0.191 \\
$\mathrm{Total} \mathrm{Fe}^{-}$ & 0.809 & 0.418 & -0.318 & 0.773 & 0.615 & 1 & 0.014 & -0.377 & -0.302 & 0.049 \\
$\mathrm{DOC}^{-}$ & -0.029 & 0.010 & 0.242 & 0.309 & 0.118 & 0.014 & 1 & 0.110 & -0.544 & -0.055 \\
$\mathrm{NO}_{3}{ }^{-}-\mathrm{N}$ & -0.485 & -0.495 & 0.000 & -0.480 & -0.603 & -0.377 & 0.110 & 1 & 0.108 & -0.091 \\
$\mathrm{NH}_{4}{ }^{+}-\mathrm{N}$ & -0.369 & -0.043 & -0.181 & -0.532 & -0.503 & -0.302 & -0.544 & 0.108 & 1 \\
Total P & 0.061 & -0.344 & -0.041 & 0.096 & -0.191 & 0.049 & -0.055 & -0.091 & 0.032 & 1 \\
\hline
\end{tabular}

highest values - it only means that the relevant effect of this variable on sample distribution is very important.

Compositional and structural differences among spring niches flora and species richness

In total, 47 vascular plant and 45 bryophyte species were recorded from 16 spring niches (Tables 5 and 6), including 33 vascular plant and 25 bryophyte species found at more than one site. There were found 20 vascular plants and 24 bryophytes ( 20 mosses, 4 liverworts) in Białystok and 41 vascular plants and 40 bryophytes (34 mosses, 6 liverworts) in KFLP. The species of bryophytes and vascular plants in two different locations were moderately correlated ( $p=0.014$ (KFLP) and $p=0.035$

Table 4 Squared cosines of the chemical parameters of spring water

\begin{tabular}{llllll}
\hline & $\mathrm{F} 1$ & $\mathrm{~F} 2$ & $\mathrm{~F} 3$ & $\mathrm{~F} 4$ & $\mathrm{~F} 5$ \\
\hline $\mathrm{pH}$ & 0.858 & 0.022 & 0.031 & 0.006 & 0.026 \\
$\mathrm{EC}$ & 0.393 & 0.059 & 0.302 & 0.001 & 0.130 \\
$\mathrm{Ca}^{2+}$ & 0.121 & 0.342 & 0.050 & 0.348 & 0.041 \\
$\mathrm{Cl}^{-}$ & 0.847 & 0.020 & 0.045 & 0.010 & 0.008 \\
$\mathrm{SO}_{4}{ }^{2-}$ & 0.811 & 0.006 & 0.035 & 0.011 & 0.026 \\
$\mathrm{Total}^{\mathrm{Fe}}$ & 0.680 & 0.012 & 0.035 & 0.011 & 0.024 \\
$\mathrm{DOC}^{-}$ & 0.022 & 0.695 & 0.000 & 0.041 & 0.201 \\
$\mathrm{NO}_{3}{ }^{-}-\mathrm{N}$ & 0.386 & 0.032 & 0.015 & 0.450 & 0.024 \\
$\mathrm{NH}_{4}{ }^{+} \mathrm{N}$ & 0.240 & 0.558 & 0.008 & 0.004 & 0.051 \\
$\mathrm{Total}^{\mathrm{P}}$ & 0.002 & 0.003 & 0.776 & 0.121 & 0.055 \\
\hline
\end{tabular}

For each variable, values in italics correspond to the factor for which the squared cosine is the largest
(Białystok) Mann-Whitney $U$ test, $p<0.05$ ). While many plants were present in both regions, only 26 vascular plant species occurred in $<20 \%$ and 17 vascular plant species in $<12 \%$ of the spring niches. Four mosses (Leptodictyum humile, Leptodictyum riparium, Plagiomnium elatum, Pterigynandrum filiforme) and one liverwort (Lophocolea heterophylla) were identified in the urban area and not found in KFLP. In general, bryophyte species observed in the Białystok region are common and resistant to anthropogenic impact (especially Leptodictyum riparium).

There have been identified 11 protected bryophytes (Calliergonella cuspidata, Campylopus pyriformis, Climacium dendroides, Dicranum scoparium, Palustriella commutata, Plagiochila asplenioides, Polytrichum commune, Thuidium philibertii,

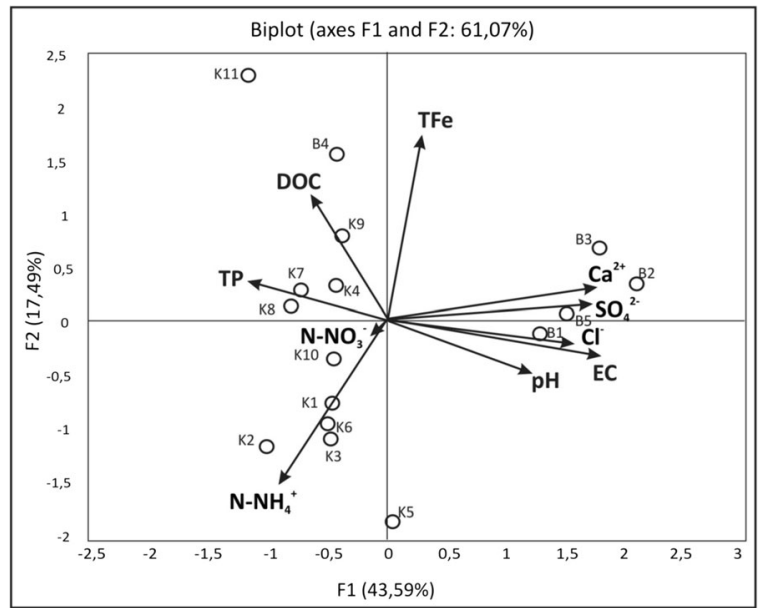

Fig. 2 Adjusted biplot scores of chemical variables with sampling sites indicating the measure of fit with the significance level $(p<0.05)$ 
Table 5 Species of vascular plants found in spring niches with relative abundance and sociability (abund., soc.)

\begin{tabular}{|c|c|c|c|c|c|c|c|c|c|c|c|c|c|c|c|c|}
\hline \multirow[t]{2}{*}{ Vascular plant species } & \multicolumn{16}{|c|}{ Spring niches } \\
\hline & B1 & B2 & B3 & B4 & B5 & K1 & $\mathrm{K} 2$ & $\mathrm{~K} 3$ & K4 & K5 & K6 & K7 & K8 & K9 & K10 & K11 \\
\hline Athyrium filix-femina & & & & & & & +0.1 & +0.1 & +0.1 & 1.1 & 1.1 & 1.1 & +0.1 & & & 1.1 \\
\hline Berula erecta & & & 1.1 & & & & & & & & & & & & +0.1 & \\
\hline Bidens tripartita & & & & & & & & & & & & & & +0.1 & & \\
\hline Carex riparia & & & & 2.3 & & & & & & & & & & 1.1 & 1.1 & \\
\hline Chrysosplenium alternifolium & & 1.1 & 2.1 & 1.1 & & & & & & & & +0.1 & & & & +0.1 \\
\hline Cardamine amara & +0.1 & & 2.2 & 1.2 & & & & & & & & & & & & \\
\hline Cicuta virosa & & & 1.1 & 1.1 & & & & & & & & & & & & \\
\hline Cirsium oleraceum & 1.1 & & & 3.2 & & 2.2 & 4.3 & 2.1 & 2.2 & 1.1 & & & 1.1 & & 2.2 & \\
\hline Epilobium ciliatum & & & & & & & & & & 1.1 & & & & & & \\
\hline Epilobium palustre & 1.1 & 1.1 & 2.1 & 1.1 & & 1.1 & 3.2 & 2.2 & 2.3 & 3.2 & 1.1 & 2.2 & 5.4 & & 2.3 & 2.2 \\
\hline Equisetum palustre & & & 1.1 & 1.1 & & & 1.1 & & +0.1 & & +0.1 & +0.1 & & & & \\
\hline Eupatorium cannabinum & & & & & & & & & & & & & & 3.2 & 1.1 & \\
\hline Filipendula ulmaria & & & & & & +0.1 & & & & & & & & & & \\
\hline Galium odoratum & & & & & & & & & & & & & +0.1 & & & \\
\hline Galium palustre & & & 2.2 & & & 2.2 & +0.1 & & 2.3 & & 2.1 & +0.1 & & +0.1 & 1.1 & 1.1 \\
\hline Geranium robertianum & & & & & & & & +0.1 & & 2.2 & & 1.1 & 1.2 & +0.1 & & +0.1 \\
\hline Glyceria fluitans & & & & & & & 3.2 & 3.2 & 2.2 & 1.1 & & 3.2 & & & 3.2 & \\
\hline Glyceria maxima & 2.3 & 1.1 & & 2.2 & & & & & & & & & & & & \\
\hline Impatiens noli-tangere & & & & & & & & & 1.1 & 1.1 & & & +0.1 & & 1.1 & \\
\hline Iris pseudacorus & & & 3.3 & & & & & & & & & & & & & \\
\hline Lemna minor & 1.2 & & & 1.2 & 2.2 & 1.2 & & 3.3 & 1.3 & 1.2 & 2.2 & 2.3 & & & & 2.2 \\
\hline Lemna trisulca & & & & & & & & & 1.3 & & & 3.3 & & 2.2 & & 4.3 \\
\hline Lycopus europaeus & & & & & & 1.1 & & & & & & & & & 1.1 & \\
\hline Lysimachia vulgaris & & & & & & +0.1 & & & & & & & & & & \\
\hline Lythrum salicaria & & & & & & 1.1 & & & & & & & & & & \\
\hline Mentha aquatica & & & & & & & 2.2 & 3.3 & & 3.2 & 1.1 & & & 3.3 & 2.3 & \\
\hline Mentha arvensis & & & & & & & & & & 1.1 & 1.1 & & & & & \\
\hline Mycelis muralis & & & & & & & & & & & & +0.1 & & & & \\
\hline Myosotis palustris & & & & & & & & & 1.2 & & & 1.1 & 1.2 & +0.1 & 1.1 & 1.1 \\
\hline Nasturtium officinale ${ }^{*}$ & & & 2.3 & +0.1 & & & & 1.2 & 4.3 & 3.2 & 4.3 & 2.2 & 3.2 & & & 2.2 \\
\hline Oxalis acetosella & & & & & & & & & +0.1 & 1.1 & 1.1 & +0.1 & +0.1 & & & 1.1 \\
\hline Phragmites australis & & & & & 4.5 & 5.5 & & & & & & & & & & \\
\hline Poa palustris & & & & & 2.2 & & & & & & & & & & & \\
\hline Polygonum amphibium & & & & & & & & & & & & & & & & +0.1 \\
\hline Ranunculus lanuginosus & & & & & & & & & +0.1 & 1.1 & 1.1 & & +0.1 & & +0.1 & \\
\hline Ranunculus repens & & & & & & & +0.1 & 1.1 & & & & +0.1 & & & & +0.1 \\
\hline Ribes spicatum & & & & & & & 1.1 & 1.1 & & & & & & & & \\
\hline Rumex aquaticus & & & & 1.1 & & 1.2 & 1.1 & & 1.1 & & & & & & & \\
\hline Rumex hydrolapathum & & & & & & & & & & & & & & & 1.2 & \\
\hline Scrophularia alata & & & & & & & & & & & & & +0.1 & & & \\
\hline Scrophularia nodosa & & & & & & & & & & & & & & & & +0.1 \\
\hline Scutellaria golericulata & & & & & & +0.1 & +0.1 & +0.1 & & & & & & & & \\
\hline Solanum dulcamara & & & & & & & +0.1 & 1.1 & & & & & & & 1.1 & \\
\hline
\end{tabular}


Table 5 (continued)

\begin{tabular}{|c|c|c|c|c|c|c|c|c|c|c|c|c|c|c|c|c|}
\hline \multirow[t]{2}{*}{ Vascular plant species } & \multicolumn{16}{|c|}{ Spring niches } \\
\hline & $\mathrm{B} 1$ & B2 & B3 & B4 & B5 & $\mathrm{K} 1$ & K2 & $\mathrm{K} 3$ & $\mathrm{~K} 4$ & K5 & K6 & K7 & K8 & K9 & K10 & K11 \\
\hline Stellaria holostea & & & & & & & & & & & & & +0.1 & & & \\
\hline Thelypteris palustris & & & 2.2 & 1.2 & & & & & & & & & & & & \\
\hline Urtica dioica & & & 1.1 & 1.1 & 1.1 & 2.3 & 2.2 & 2.2 & 1.3 & 1.1 & 3.2 & 1.2 & 1.2 & 1.2 & 1.2 & 1.2 \\
\hline Veronica beccabunga & & 1.1 & 1.1 & 1.1 & & & & 2.1 & 2.2 & 1.2 & & 1.1 & 1.1 & & 2.3 & 2.2 \\
\hline
\end{tabular}

*Protected species

T. tamariscinum) (Hypnum pratense and Leptodictyum humile). In Białystok, it was found one protected moss (Leptodictyum humile), identified in spring niches B2 and B3, and one protected liverwort (Plagiochila asplenioides), identified in spring niche $\mathrm{B} 1$.

The species richness measures for the investigated plant species reflect the diversity of the spring niches in both investigated environments (Table 1). No statistically significant differences were observed for the species diversity index (Fig. 3, Table 7). The greatest floristic diversity was observed in spring niches B4, B2, K5, and $\mathrm{K} 10$ and the least in $\mathrm{B} 1, \mathrm{~B} 3$, and $\mathrm{K} 8$. The index of floral originality indicates the similarity of spring niches in the KFLP in terms of species structure. However, the IFO values in sampling sites B1, B2, and B3 were falsely specified because of very low vascular plant species richness. Spring niches in the KFLP have higher values for the index of bryophyte originality than springs located in Białystok, with the exception of sampling site B4, where the IFO valued 49.2. Using Welch's $t$ test, significant differences in the mean values of biodiversity indicators between springs located in Białystok and in KFLP were assessed separately for vascular plants and bryophytes. On average, species richness of springs located in KFLP showed values two to three times higher than springs in Białystok (Fig. 3).

Two-way MANOVA shows that there is no statistically significant interaction between water quality and location for species richness with spring area as a covariate $(F=51,053, p=0.105$; Wilk's $\Lambda=0.005)$.

Effects of environmental variables on individual species

The relationship between vascular plants, bryophytes, and environmental variables at the 16 sampling sites was evaluated by CCA and is presented graphically (Figs. 4 and 5). Species data obtained in the study are unimodal along the defined gradients (electrolytic conductivity, $\mathrm{NO}_{3}{ }^{-}-\mathrm{N}, \mathrm{NH}_{4}{ }^{+}-\mathrm{N}, \mathrm{SO}_{4}{ }^{2-}$, and $\mathrm{Cl}$ ). $\mathrm{CCA}$ was carried out to assess which of the selected variables characterizing spring niches exerted the greatest impact on the diversity of their floristic composition. The following factors played important roles: the concentration of nutrients, ammonium ions, and DOC. Ordering of vascular plant species based on their quantitative share in niches showed that the existing plants could be grouped according to the habitat gradients - from fertile habitats rich in organic matter to poorly fertile, mineralrich habitats. The CCA shows that urban spring niches are characterized by the presence of bryophytes related to the anthropogenic environment. The highest number of bryophyte species is associated with those concentrations of selected nutrients and DOC (Fig. 5). In this case, mosses show responses quite different from those of angiosperms, whereas the angiosperm CCA biplot is mostly the same as the water quality PCA.

\section{Discussion}

Our results show that preferences of bryophyte and vascular plant species in the studied spring niches are similar along the main environmental gradients and different in water chemistry. Bryophyte and vascular plant species richness were positively related in all studied sites $(r=$ 0.3921; $p<0.05$ ), independent of the niche transformation. Vascular plants and bryophytes have similar habitat requirements in lowland springs. This means that similar methods can be used to protect the large-scale richness of those two taxonomic groups in spring niches, as also described in two wetland nature reserves in Estonia (Ingerpuu et al. 2001). However, research in western Norway indicates differences in habitat requirements between vascular plants and bryophytes. For these two 
Table 6 Bryophyte species found in spring niches and their protection status

Bryophytes species Spring niches

$\begin{array}{llllllllllllllll}\mathrm{B} 1 & \mathrm{~B} 2 & \mathrm{~B} 3 & \mathrm{~B} 4 & \mathrm{~B} 5 & \mathrm{~K} 1 & \mathrm{~K} 2 & \mathrm{~K} 3 & \mathrm{~K} 4 & \mathrm{~K} 5 & \mathrm{~K} 6 & \mathrm{~K} 7 & \mathrm{~K} 8 & \mathrm{~K} 9 & \mathrm{~K} 10 & \mathrm{~K} 11\end{array}$

Liverworts

Chilloscyphus pallescens

Conocephalum conicum

Lophocolea heterophylla

Marchantia polymorpha

Pellia endiviifolia

Pellia neesiana

Plagiochila asplenioides*

Mosses

Brachythecium mildeanum

Brachythecium rivulare

Brachythecium rutabulum

Bryum pallens

Bryum pseudotriquetrum

Calliergonella cuspidata*

Campylopus pyriformis*

Climacium dendroides*

Cratoneuron filicinum

Dicranella staphylina

Dicranum scoparium*

Homomallium incurvatum

Hygrohypnum luridum

Hypnum cupressiforme

Hypnum pratense*

Leptodictyum humile*

Leptodictyum riparium

Mnium hornum

Palustriella communata*

Plagiomnium elatum

Plagiomnium ellipticum

Plagiomnium medium

Plagiomnium undulatum

Plagiothecium nemorale

Plagiothecium ruthei

Platyhypidium riparioides

Pohlia nutans

Pohlia wahlenbergii

Polytrichum commune*

Pseudobryum cinclidoides

Pterigynandrum filiforme

Rhizomnium punctatum

Rhytidiadelphus subpin.

Sanionia uncinata

+
+
+

$+$

$+$


Table 6 (continued)

\begin{tabular}{|c|c|c|c|c|c|c|c|c|c|c|c|c|c|c|c|c|}
\hline \multirow[t]{2}{*}{ Bryophytes species } & \multicolumn{16}{|c|}{ Spring niches } \\
\hline & $\mathrm{B} 1$ & $\mathrm{~B} 2$ & B3 & B4 & B5 & $\mathrm{K} 1$ & $\mathrm{~K} 2$ & $\mathrm{~K} 3$ & K4 & K5 & K6 & K7 & K8 & K9 & K10 & K11 \\
\hline Schistidium apocarpum & & & & & & & & & & & + & & & & & \\
\hline Thuidium abietinum & & & & & & & & & & & + & & & & & \\
\hline Thuidium philibertii* & & & & & & & & & & + & + & & + & & & \\
\hline Thuidium tamariscinum* & & & & & & & & & + & + & & + & & & & + \\
\hline
\end{tabular}

*Protected species

taxonomic groups, species richness responds very differently to altitude (Grytnes et al. 2006).

Forty-five bryophyte species representing various ecological groups and growing on a variety of microhabitats were identified in the studied springs: aquatic (e.g., Brachythecium rivulare, Calliergonella cuspidata, Platyhypnidium riparioides), epixylic and epiphytic (growing on logs or stumps of trees, e.g., Brachythecium rutabulum, Lophocolea heterophylla, Marchantia polymorpha), and terrestrial species (growing on soil or humus, e.g., Polytrichum commune, Rhytidiadelphus subpinnatus, Thuidium tamariscinum). Most of the identified bryophyte species are typical of the springs and river valleys of central and eastern Poland (Czarnecka 2009; Czarnecka and Janiec 2007; Mazurek 2008; Mazurek 2006; Grzelak 2011). Similar species were identified by Fudali et al. (2015) during a study on the distribution of bryoflora in the upper valley

\section{A) Vascular plants}
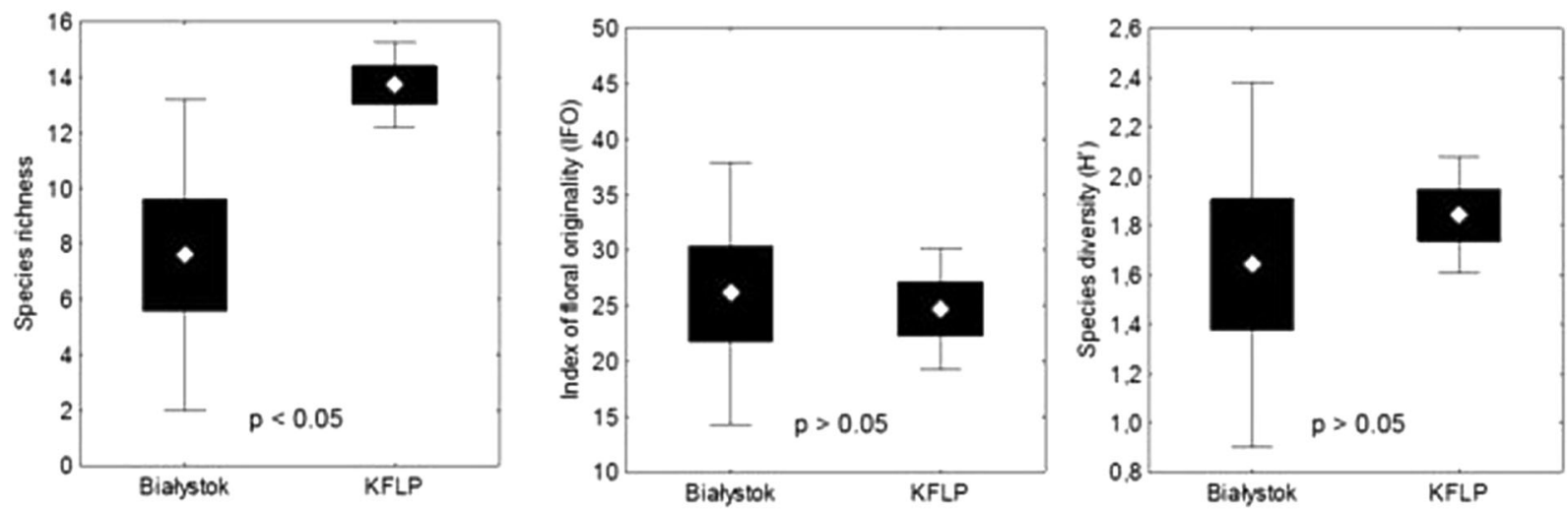

B) Bryophytes
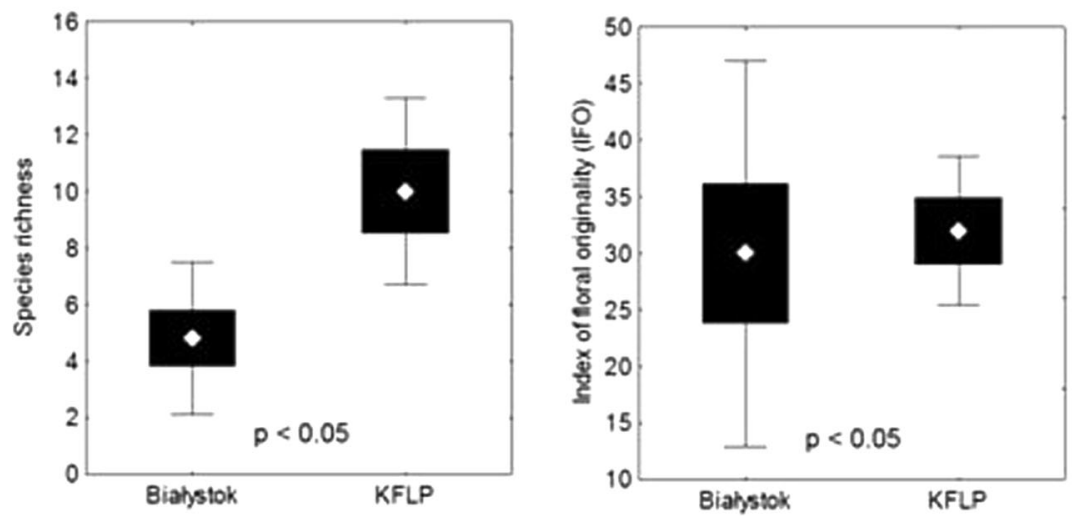

Fig. 3 The values of the biodiversity metrics in two locations (mean \pm standard error \pm 0.95 confidence interval) and results of Welch's test 


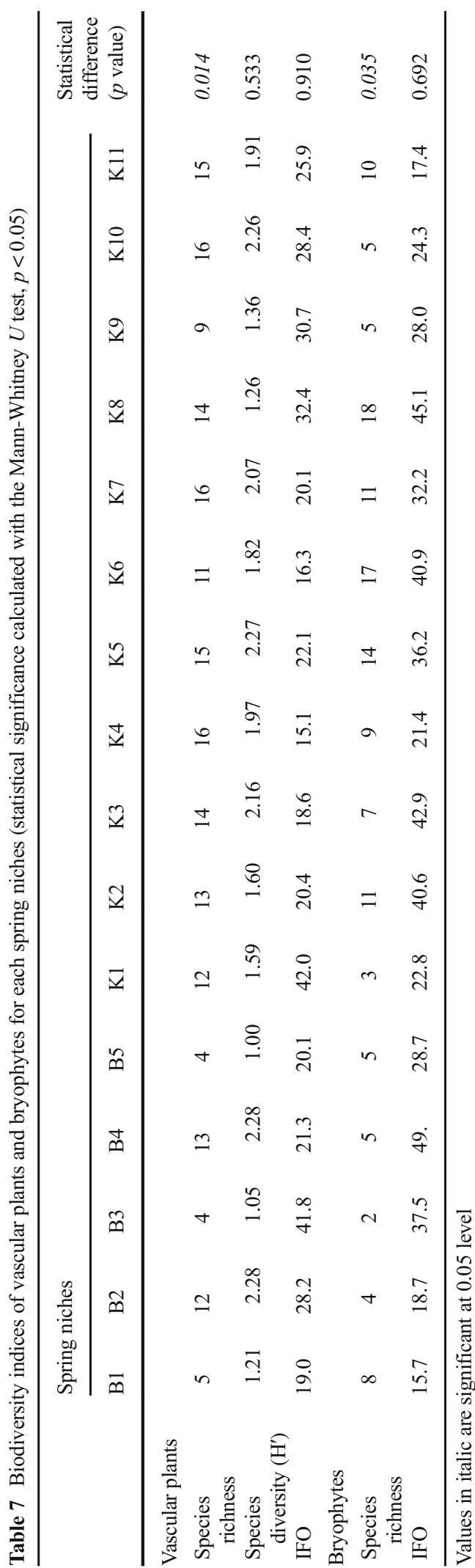

of Świerszcz stream in Roztocze National Park (75\% of common species).

Some evidence was observed for segregation of species according to water chemistry. Several of the environmental factors measured in this study show significant impact on the flora of spring niches (Table 2). The concentration of nutrients was positively correlated with vascular plants in springs in KFLP (Table 7). Most of the springs in KFLP were close to a natural state (Table 1). Furthermore, the degree of naturalness in the catchment does not correlate with species richness (Table 7). Some of spring niches located in urban areas were characterized by higher values of Shannon's species diversity index than were observed for spring niches in KFLP. The floral originality index was associated with the condition and morphology of spring niches (Table 7). This is particularly evident in two studied limnocrenes: nos. $\mathrm{B} 3$ and $\mathrm{K} 4$, where CCAs show similarities in the chemical characteristics of water but differences in floral structure resulting from the catchment management (Table 1, Figs. 4 and 5). Spring no. B3, located in an urban area, has a poorer ecological status, with the lowest flora species richness and the lowest Shannon's species diversity. Bryophytes showed a stronger response than vascular plants to water quality, because bryophytes absorb nutrients only from spring water.

Research by Jekatierynczuk-Rudczyk (2008) indicates that the water quality of springs located in the city is slightly different compared to the hydrochemical background of springs located in the Supraśl river catchment. The surface waters of lowland areas of northeastern Poland, especially in forests and wetlands, are characterized by elevated concentrations of organic matter, which can also be noticed in the springs (Zieliński et al. 2016). Water chemistry of springs is affected not only by flowing groundwater but also by changes in the morphology of the outflow of the spring niche (Chapman et al. 1993). Low temperature reduces the rate of biomass decomposition and favors the accumulation of organic matter (Wołejko 2000). The hydrochemical types of spring water in Bialystok show disturbing symptoms associated with human activity (Jekatierynczuk-Rudczyk 2007, 2008). Our results indicate higher ranges of $\mathrm{pH}$ and EC for water from Białystok springs, which probably results from transformations of urban catchment. Our research confirms that the chemical composition and morphological factors play important roles in structuring the floristic composition and diversity of plant communities in springs (Zechmeister and Mucina 1994; Sołtys- 


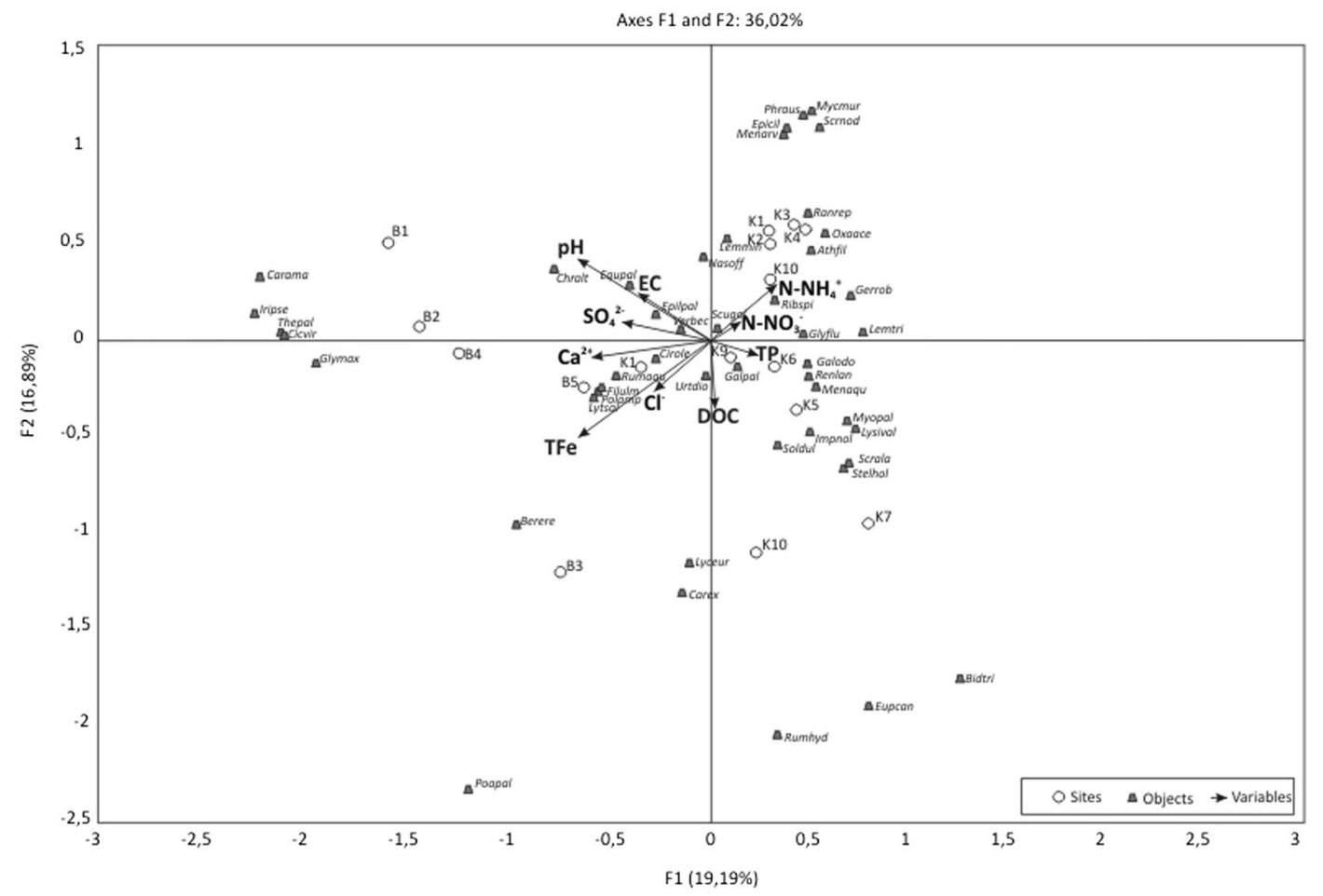

Fig. 4 CCA ordination diagram of vascular plants and environmental variables based on 16 sampling sites

Lelek et al. 2014). Furthermore, the species of vascular plants that are characteristic of spring areas, such as Cardamine amara and Chrysosplenium alternifolium, correspond with urban spring niches, which may be the result of shading. The springs in KFLP were characterized by higher similarity in species composition of vascular plants and bryophytes than in Białystok springs (Tables 5 and 6). The location of springs in forested areas favors the growth of sciophytes.

Many aquatic bryophyte species are used in bioindicator methods of watercourse assessment (i.e., Haury et al. 2006; Holmes et al. 1999; Meilinger et al. 2005; Szoszkiewicz et al. 2010; Willby et al. 2009). Most of them are typical indicators of low concentrations of nutrients in water (especially orthophosphates; Szoszkiewicz et al. 2010), although a few tolerant species (e.g., Leptodictyum riparium, L. humile) indicate anthropogenic degradation of watercourses (Ceschin et al. 2012; Vanderpoorten 1999). In the studied springs, concentrations of nutrients were slightly higher in springs located in the KFLP region, but in the vast majority, the nutrient concentrations corresponded to generally accepted criteria for this type of lowland watercourse (Jusik et al. 2015; Pardo et al. 2012; Wallin et al. 2003): total phosphorus $<0.2 \mathrm{mg} \mathrm{P} \mathrm{dm}^{-3}$, nitrate nitrogen $<1.0 \mathrm{mg} \mathrm{N} \mathrm{dm}^{-3}$, ammonium nitrogen $<0.2 \mathrm{mg} \mathrm{N} \mathrm{dm}^{-3}$. Probably for this reason, bioindicators of oligotrophy and mesotrophy occurred in many of the studied springs (Table 6): Brachythecium rivulare, Bryum pseudotriquetrum, Calliergonella cuspidata, Chiloscyphus pallescens, Conocephalum conicum, Cratoneuron filicinum, Hygrohypnum luridum, Palustriella commutata, Pellia endiviifolia, Platyhypnidium riparioides, and Schistidium apocarpum. Meanwhile, springs located in Bialystok city were dominated by two species associated with human activity: Leptodictyum riparium and Leptodictyum humile (Ceschin et al. 2012).

Compared to 100 taxa identified in the spring niches of the Łódź city (Grzelak 2011), the spring niches of Białystok are poor in vascular plants. However, crenophytes have been recorded (Cardamine amara, Chrysosplenium alternifolium, Brachythecium rivulare, Leptodictyum humile, Plagiochila asplenioides), indicating that the ecological status of the environment is fairly good. Spring niches located in the Nida river catchment area were characterized by an even lower biodiversity of flora. In 21 springs, only 9 showed the presence of vascular plants, amounting to a range of 510 species (Chwalik-Borowiec et al. 2011). The small 


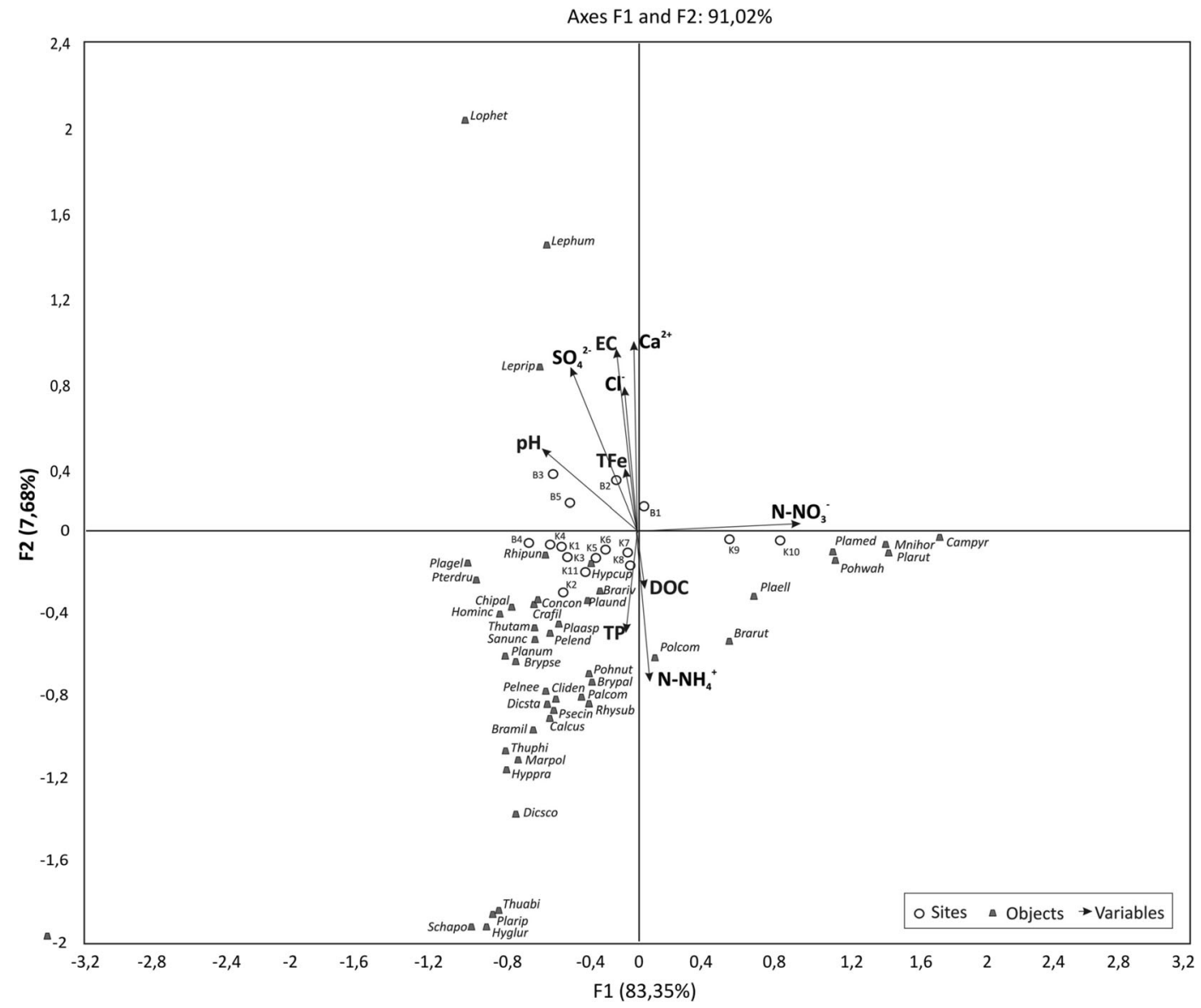

Fig. 5 CCA ordination diagram of bryophytes and environmental variables based on 16 sampling sites

number of vascular plants was likely related to the strong transformation of outflows (in most cases, wells, chapels, and houses were present). Moreover, spring niches with vascular plants were characterized by a very small surface area of not more than $3 \mathrm{~m}^{2}$.

The existence of many valuable species in the spring niches of Bialystok suggests the necessity of their legal protection. In Poland, there are only 134 springs protected by law. The state of knowledge about springs is insufficient, so the increasing anthropogenic pressure and changes in water circulation may affect the disappearance of many natural outflows. The flora of spring niches is a good indicator that can be useful in the planning of preventive measures. Bryophytes are sensitive indicators of environmental changes, and many bryophytes are thus particularly threatened by the degradation of habitats (Juutinen 2011; Vanderpoorten 1999). Studies by Heino et al. (2005) and Kapfer et al. (2012) show that the persistence and stability of bryophyte communities are associated with good conditions of the springs. Floristic diversity research on spring niches in northeastern Poland suggests that the presence or absence of crenophytes is indicative of the ecological status of the groundwater outflow complexes. The presence of species under protection indicates a high degree of naturalness of the environment. The occurrence of Palustriella commutata in KFLP is interesting because this species is described as a typically calcicole moss (Bain and Proctor, 1980). However, it also occurs in the crystalline Tatras on siliceous bedrock (Smieja 2014). The geological structure of the Krzemianka Reserve is dominated by carbonate gravels with significant admixture of flint. It is one of the KFLP groundwater outflows where EC is the highest, which confirms the dissolution of carbonates (Jekatierynczuk-Rudczyk 2010).

Anthropogenic activity significantly affects the biodiversity of the flora of lowland springs. Biodiversity in spring niches depends not only on the outflow yield, the geological structure of the saturation zone, and the spring exposure but also on water quality (mainly the 
concentrations of nutrients, ammonium ions, and DOC). Plant community richness combined with the environmental factors (water quality, geological, morphological, hydrological) can be a good indicator of the ecological status of lowland springs.

Acknowledgements The authors would like to thank Piotr Jadwiszczak for substantial assistance with statistical methods in this research project.

Open Access This article is distributed under the terms of the Creative Commons Attribution 4.0 International License (http:// creativecommons.org/licenses/by/4.0/), which permits unrestricted use, distribution, and reproduction in any medium, provided you give appropriate credit to the original author(s) and the source, provide a link to the Creative Commons license, and indicate if changes were made.

\section{References}

APHA (1992). Standard methods for the examination of water and waste water, 18th ed. American.

Bain, J., \& Proctor, M. (1980). The requirement of aquatic bryophytes for free $\mathrm{CO}_{2}$ as an inorganic carbon source: some experimental evidence. The New Phytologist, 86, 393-400.

Braun-Blanquet, J. (1932). Plant sociology. New York: McgrawHill Book Company, Inc.

Ceschin, S., Aleffi, M., Bisceglie, S., Savo, V., \& Zuccarello, V. (2012). Aquatic bryophytes as ecological indicators of the water quality status in the Tiber River basin (Italy). Ecological Indicators, 14, 74-81.

Chapman, P. J., Reynolds, B., \& Wheater, H. S. (1993). Hydrochemical changes along stream pathways in a small moorland headwater catchment in Mid-Wales, UK. Journal of Hydrology, 151, 241-265.

Chełmicki, W., Jokiel, P., Michalczyk, Z., \& Moniewski, P. (2011). Distribution, discharge and regional characteristics of springs in Poland. Episodes, 34, 244-256.

Chwalik-Borowiec, A., Jóźwiak, K., Sołtys-Lelek, A., Lelek, K., \& Różkowski, J. (2011). Remarks about spring zones in the karst areas of the Niecka Nidziańska Region. 45. Materials Sympozjum of Speleological, Kraków, 47-48, (In Polish).

Cliff, N. (1988). The eigenvalues-greater-than-one rule and the reliability of components. Psychological Bulletin, 103, 276-279.

Czarnecka, B. (2009). Springs of the Roztocze escarpment zone: the diversity of plant cover vs. environment quality. Infrastructure and Ecology of Rural Areas, 6, 27-43 (In Polish).

Czarnecka, B., \& Janiec, B. (2007). The effect of spring waters on the differentiation of vegetation in river breaks of the Roztocze Tomaszowskie escarpment zone. In P. Jokiel, P. Moniewski, \& M. Ziułkiewicz (Eds.), Springs of Poland. Crenological selected problems (pp. 253-264). Lodz: Faculty of Geographical Sciences, University of Lodz (In Polish).

Ejsmont-Karabin, J. (1995). Rotifer occurrence in relation to age, depth and trophic state of quarry lakes. Hydrobiologia, 313, 21-28.
Fudali, E., Zubel, R., Stebel, A., Rusinska, A., Gorski, P., Voncina, G., Rosadzinski, S., Cykowska-Marzencka, B., StanaszekKik, M., Wierzcholska, S., Wolski, G. J., Wojterska, M., Wilhelm, M., Paciorek, T., \& Piwowarski, B. (2015). Contribution to the bryoflora of the Roztocze National Park (SE Poland) - bryophytes of the Swierszcz river valley. Steciana, 19, 39-54.

Grytnes, J. A., Heegaard, E., \& Ihlen, P. G. (2006). Species richness of vascular plants, bryophytes, and lichens along an altitudinal gradient in western Norway. Acta Oecologica, 29, 241-246.

Grzelak, P. (2011). The vascular plants of the forest spring niches in the region of Łódź. Nature Overview, 22, 38-45 (In Polish).

Hadač, E. (1983). A survey of plant communities of springs and mountain brooks in Czechoslovakia. Folia Geobotanica et Phytotaxonomica, 18, 339-361.

Haury, J., Peltre, M. C., Trémolières, M., Barbe, J., Thiébaut, G., Bernez, I., Daniel, H., Chatenet, P., Haan-Archipof, G., Muller, S., Dutartre, A., Laplace-Treyture, C., Cazaubon, A., \& Lambert-Servien, E. (2006). A new method to assess water trophy and organic pollution - the Macrophyte Biological Index for Rivers (IBMR): its application to different types of river and pollution. Hydrobiologia, 570, 153-158.

Heino, J., Virtanen, R., Vuori, K. M., Saastamoinen, J., Ohtonen, A., \& Muotka, T. (2005). Spring bryophytes in forested landscapes: land use effects on bryophyte species richness, community structure and persistence. Biological Conservation, 124, 539-545.

Holmes, N. T. H., Newman, J. R., Chadd, S., Rouen, K. J., Saint, L., \& Dawson, F. H. (1999). Mean trophic rank: a user's manual, R\&D Technical Report E38. Environment Agency.

Ingerpuu, N., Vellak, K., Kukk, T., \& Pärtel, M. (2001). Bryophyte and vascular plant species richness in boreo-nemoral moist forests and mires. Biodiversity and Conservation, 10, 21532166.

Jekatierynczuk-Rudczyk, E. (2007). Characteristics of the water quality in springs of Białystok. In P. Jokiel, P. Moniewski, \& M. Ziułkiewicz (Eds.), Springs of Poland. Crenological selected problems (Vol. 44, pp. 234-241). Lodz: Faculty of Geographical Sciences, University of Lodz (In Polish).

Jekatierynczuk-Rudczyk, E. (2008). Threats to a small river and its urban catchment. Ecohydrology and Hydrobiology, 8, 77-87.

Jekatierynczuk-Rudczyk, E. (2010). Transformation in physicochemical composition of groundwaters within lowland drainage zones (pp. 1-224). Białystok: Wyd. UwB (In Polish with English summary).

Jekatierynczuk-Rudczyk, E., Zieliński, P., \& Puczko, K. (2017). Is the protection of springs in Knyszyn Forest effective and satisfactory? Protect Native Nature, 73, 135-147 (In Polish with English summary).

Jonczak, J. (2013). Pedological aspects in the functioning of spring niches as transition zones between underground and superficial parts of the water cycle in a river basin. Ecological Questions, 15, 35-43.

Jusik, S., Szoszkiewicz, K., Kupiec, J. M., Lewin, I., \& SameckaCymerman, A. (2015). Development of comprehensive river typology based on macrophytes in the mountain-lowland gradient of different Central European ecoregions. Hydrobiologia, 745, 241-262. 
Juutinen, R. (2011). The decrease of rich fen bryophytes in springs as a consequence of large-scale environmental loss. A 50year re-sampling study. Lindbergia, 34, 2-18.

Kaiser, H. F. (1960). The application of electronic computers to factor analysis. Educational and Psychological Measurement., 20, 141-151.

Kapfer, J., Audorff, V., Beierkuhnlein, C., \& Hertel, E. (2012). Do bryophytes show a stronger response than vascular plants to interannual changes in spring water quality? Freshwater Science, 31, 625-635.

Kucharski, L. (2007). Flora of springs - a composition and diagnostic species. In P. Jokiel, P. Moniewski, \& M. Ziułkiewicz (Eds.), Springs of Poland. Crenological selected problems (pp. 62-68). Lodz: Faculty of Geographical Sciences, University of Lodz (In Polish).

Lacoul, P., \& Freedman, B. (2006). Environmental influences on aquatic plants in freshwater ecosystems. Environmental Reviews, 14, 89-136.

Legendre, P., \& Gallagher, E. D. (2001). Ecologically meaningful transformations for ordination of species data. Oecologia, $129,271-280$.

Legendre, P., \& Legendre, L. (1998). Numerical ecology: second English edition. Developments in Environmental Modeling, p. 20, Elsevier, Amsterdam.

Mazurek, M. (2006). Morphometric differences in channel heads in a postglacial zone (Parsęta catchment, West Pomerania). Quaestiones Geographicae, 25, 39-47.

Mazurek, M. (2008). Spring niches areas with a link between the cone system and the trough system, the Parseta river basin. Landform Analysis, 9, 63-67.

McKinney, M. L. (2008). Effects of urbanization on species richness: a review of plants and animals. Urban Ecosystems, 112, $161-176$

Meilinger, P., Schneider, S., \& Melzer, A. (2005). The reference index method for the macrophyte-based assessment of rivers - a contribution to the implementation of the European Water Framework Directive in Germany. International Review of Hydrobiology, 90, 322-342.

Michalik, A. (2008). The use of chemical and cluster analysis for studying spring water quality in Świętokrzyski National Park. Polish Journal of Environmental Studies, 17, 357-362.

Mirek, Z., Piekoś-Mirkowa, H., Zając, A., \& Zając, M. (2002). Flowering plants and pteridophytes of Poland. A checklist. Biodiversity of Poland (Vol. 1). Kraków: Polish Academy of Sciences, Institute of Botany.

Ochyra, R., Żarnowiec, J., \& Bednarek-Ochyra, H. (2003). Genus catalogue of polish mosses. Biodiversity of Poland (Vol. 3). Kraków: Polish Academy of Sciences, Institute of Botany.

Osadowski, Z., \& Strzelczak, A. (2010). Influence of iron and manganese contents in ground water outflows on vegetation diversity in spring ecosystems of the middle Pomerania. Fresenius Environmental Bulletin, 19, 354-361.

Ouyang, Y. (2005). Evaluation of river water quality monitoring stations by principal component analysis. Water Research, 39, 2621-2635.

Pardo, I., Gómez-Rodríguez, C., Wasson, J.-G., Owen, R., van de Bund, W., Kelly, M., Bennett, C., Birk, S., Buffagni, A., Erba, S., Mengin, N., Murray-Bligh, J., \& Ofenböeck, G. (2012). The European reference condition concept: a scientific and technical approach to identify minimally-impacted river ecosystems. The Science of the Total Environment, 420, 33-42.
Rysiak, A., \& Czarnecka, B. (2015). Urban heat island vs. flora features in the Lublin city area, SE Poland. In M. Boltižiar, A. Bača (Ed.) Landscape and Landscape Ecology, p. 32, Nitra, Slovakia.

Shannon, C. E., \& Weaver, W. (1963). The mathematical theory of communication. Urbana: Univ. Illinois Press.

Smieja, A. (2014). Flora of springs in the Polish Tatra Mountainshabitat and phytosociological characteristics of crenophiles. Biodiversity: Research and Conservation, 36, 25-36.

Sołtys-Lelek, A., Barabasz-Krasny, B., \& Różkowski, J. (2014). Participation of various habitat groups in the flora of springs niches in the Ojców National Park (Southern Poland). Biodiversity: Research and Conservation, 36, 37-51.

Springer, A. E., \& Stevens, L. E. (2009). Spheres of discharge of springs. Hydrogeology Journal, 17, 83-93.

Szoszkiewicz, K., Zbierska, J., Jusik, S., \& Zgoła, T. (2010). Macrophyte method for river assessment-manual for the assessment and classification of ecological status of running waters based on the aquatic plants. Poznań: Bogucki Scientific Publishing (In Polish).

Szweykowski, J. (2006). An annotated checklist of Polish liverworts and hornworts. Biodiversity of Poland (Vol. 4). Kraków: Polish Academy of Sciences, Institute of Botany.

Vanderpoorten, A. (1999). Aquatic bryophytes for a spatiotemporal monitoring of the water pollution of the rivers Meuse and Sambre (Belgium). Environmental Pollution, 104, 401-410.

Wallin, M., Wiederholm, T., \& Johnson, R. (2003). Guidance on establishing reference condition and ecological status class boundaries for inland surface waters. Final Report to the European Commission from CIS Working Group 2.3. REFCOND.

Warncke, E. (1980). Spring areas: ecology, vegetation, and comments on similarity coefficients applied to plant communities. Holarctic Ecology., 3, 233-308.

Willby, N., Pitt, J. A., \& Phillips, G. (2009). The ecological classification of UK rivers using aquatic macrophytes. $U K$ Environment Agency Science Reports. Project SC010080 /SR1. Environmental Agency, Bristol.

Wojtal, A. Z. (2013). Species composition and distribution of diatoms assemblages in spring waters from various geological formations in southern Poland. Bibliotheca Diatomologica, $59,1-436$

Wołejko, L. (2000). Phytosociological and ecological dynamics of the spring niches ecosystems of north-western Poland under the conditions of the agriculture extensification. (Doctoral dissertation, Publisher of the Academy of Agriculture) (In Polish).

Zechmeister, H., \& Mucina, L. (1994). Vegetation of European springs: high-rank syntaxa of the Montio-Cardaminetea. Journal of Vegetation Science, 5, 385-402.

Żelazna-Wieczorek, J., \& Maninska, M. (2006). Algoflora and vascular flora of a limestone spring in the Warta River valley. Acta Societatis Botanicorum Poloniae, 75, 131-143.

Zieliński, P., \& Górniak, A. (1999). Analysis of dissolved organic carbon in natural waters. ABiD., 3, 37-45.

Zieliński, P., Grabowska, M., \& Jekatierynczuk-Rudczyk, E. (2016). Influence of changeable hydro-meteorological conditions on dissolved organic carbon and bacterioplankton abundance in a hypertrophic reservoir and downstream river. Ecohydrol, 9, 382-395. 